"Through the thin bottom of the top nest I could faintly see a whitish object. By pushing the material in the bottom aside I found there was one brown-headed cowbird egg, one whole yellow warbler egg, and fragments of a second yellow warbler egg."

Further enquiries and discussions have led me to conclude that parisitism of the original nest (used for a second clutch) must have taken place sometime toward the end of June and/or beginning of July (when the female had decided to have a second brood and had laid two eggs in it.)

After the nest had been parasitized she then evidently decided to build a second storey on the nest and laid three eggs therein.

It would appear that the history of this nest is unusual in that:

1. First nesting was completed by 2 June with at least two fledglings.

2. A second nesting was attempted in the same nest, with two Yellow Warbler eggs; parasitized with one cowbird egg.

3. A second nesting was completed on 27 July with three fledglings.

1BENT, A. C. 1953. Life histories of North American wood warblers. U.S. Nat. Mus. Bull. 203. 734 pp.

2GODFREY, W. E. 1966. The birds of Canada. Nat. Mus. Canada Bull. 203. $428 \mathrm{pp}$.

3PETERSON, R. T. 1969. A field guide to western birds. Houghton Mifflin, Boston. 366 pp.

${ }^{4}$ ROBBINS, C. S., B. BRUUN and H. S. ZIM. 1966. A guide to identification, Birds of North America. Golden Press, New York. 340 pp.

5 UDVARDY, M. D. F. 1977. The Audubon Society field guide to North American birds. Western Region. A. A. Knopf, New York.

\section{COMMENTS ON THE WHYEWOLD WARBLER}

J. B. GOLLOP, 2202 York Avenue, Saskatoon, Saskatchewan, S7J 1J1.

Jean Bancroft's Yellow Warbler nesting was indeed a rare occurrence. A wider search of the literature confirms its rarity in three aspects: second brood, same nest and nest construction.

While the observation cannot be accepted as irrefutable evidence of a second brood (because the bird was not marked), it may be the strongest evidence yet accumulated. The only other hint of more than one brood in a season comes from the Oneida Lake district of north-central New York: "Usually one brood is reared in a season, but we have some evidence to indicate two broods sometimes may be reared ...".10 While eggs have been found from May through June and into July, the usual explanation for such a long season is destruction of first nests or desertion of these due to cowbird parasitism. 11

There is also a general reference as follows: "North American (warblers), with rare exceptions, rear only a single brood each year'" 8 Among species breeding in the Prairie Provinces, the Yellowthroat is known to have two broods while the Yellowrumped, Black-throated Green and Palm warblers may have. ${ }^{4} 9$ However, even for these species, multiple broods may not occur as far north as our latitudes.

There are two pieces of evidence to suggest the rarity of second broods, both from lowa. A study of marked birds found that Yellow Warblers could not be found in the vicinity of their nests more than 7 to 10 days after the young had left nor 
were the birds found to renest elsewhere. ${ }^{7}$ The other observation is that this "was among the first warbler species to begin its southward migration. The easily recognized flight notes were heard at night and in early morning, as early as 18-19 June (1932). By early July they could be heard almost nightly, and in very early mornings the transients could be seen flying over or dropping from considerable height to alight in bushes and trees". 12

This may be the first example of a Yellow Warbler's nest being used twice in a season. None of the authorities listed below suggest it and the situation probably applies to many species as the following indicates: "Among passerine birds, as well as many other groups, it is exceptional for pairs to renest in the same nest or at the same nesting site". 6

Finally, the use of paper in a Yellow Warbler nest may not have been reported previously. The use of any man-made material is apparently unusual. Wool and cotton have been found in nests but these may have been natural or processed.1 3 The only other artificial material mentioned was "a piece of string". 5

The Whyewold warbler, however, was not unique in covering cowbird eggs. The Yellow Warbler may be the only species that does this, although more than 200 other species are parasitized by Brown-headed Cowbirds. ${ }^{2}$ The record is held by a bird that built a six-storey nest, each storey having a cowbird's egg. ${ }^{1}$
1BENT, A. C. 1953. Life histories of North American wood warblers. U.S. Nat Mus. Bull. 203. 734 pp.

2 FRIEDMANN, HERBERT, L. F. KIFF ane S. I. ROTHSTEIN. 1977. A further con tribution to knowledge of the hos relations of the parasitic cowbirds Smithsonian Contrib. Zool. 235. 75 pp

3 HARRISON, COLIN. 1978. A field guide to the nests, eggs and nestlings of North American birds. Collins, New York $416 \mathrm{pp}$.

4HARRISON, H. H. 1975. A field guide to birds' nests. Houghton Mifflin Boston. 257 pp.

5JEWETT, S. G., W. P. TAYLOR, W. T SHAW and J. W. ALDRICH. 1953 Birds of Washington State. Univ Wash. Press, Seattle. 767 pp.

6PETTINGILL, O. S., Jr. 1970. Ornithology in laboratory and field. Burgess, Min neapolis. $524 \mathrm{pp}$.

7SCHRANTZ, F. G. 1943. Nest life of the Eastern Yellow Warbler. Auk 60:367387.

8SKUTCH, A. F. 1957. An introduction to the warbler family. Pages 3-7 in L. Griscom and A. Sprunt, Jr., eds., The warblers of North America. DevinAdair, New York.

9STEWART, R. E. 1953. A life history study of the Yellow-throat. Wilson Bull. 65:99-115.

10STONER, DAYTON. 1932. Ornithology of the Oneida Lake region: with reference to the late spring and summer seasons. Roosevelt Wild Life Annals 2( 3 \& 4):277-760.

11 TOZER, R. G., and J. M. RICHARDS. 1974. Birds of the Oshawa-Lake Scugog region, Ontario. Privately published (Alger Press, Oshawa). 384 pp.

12TRAUTMAN, M. B. 1940. The birds of Buckeye Lake, Ohio. Misc. Publ. Mus. Zool., Univ. Michigan 44. 466 pp. 